\title{
Training of Moria choir conductor members and conductors in efforts to improve quality in Medan city
}

\author{
Frida Deliana $^{1 *}$, Suprayitno ${ }^{1}$ \\ ${ }^{1}$ Faculty of Cultural Studies, Universitas Sumatera Utara, Medan, Indonesia \\ *Email: fridadeliana1@gmail.com
}

\begin{abstract}
In ecclesiastical worship activities in the Christian community, singing activities both in the format of 'choir', congregational singing and others are integrated in a series of worship services in the church. It is also found among members of the Runggun Benameriah Protestant Karo Batak Church (GBKP) congregation who also use the choir format in activities to praise and glorify God. For Christians singing is a spiritual need. In both churches there are several types of choirs, both the choir moria (mothers), mamre choirs (fathers) gem choirs or youth / youth and elderly choirs. Each choir has a trainer (amateur) who also acts as choir leader, referred to as Dirigen. The problem is that often the quality of the choir that is displayed is low. This means that there are always a lot of technical errors and un-melodious voices from the choir members during the choir presentation. If this condition continues and occurs continuously, the presence of the choir can eventually interfere with the implementation of worship. Another condition is that almost all Dirigens in the GBKP choir are people who have limited musical abilities, and have no background in formal music education. His managerial ability and technical ability to teach choir is very weak. Dirigen's lack of musical knowledge and technical ability will certainly have a profound impact on the quality of the choir he leads. Therefore this dedication team will improve the choir management ability in vocal material and the ability of conducting to all participants so as to minimize the technical difficulties found in the preparation and presentation of the choir. This community service activity is expected that members and conductors / choir leaders can utilize their knowledge and experience as professionals in the field of choir training among community members in general.
\end{abstract}

Keyword: training, choir conductor and members.

\begin{abstract}
Abstrak
Di dalam aktivitas peribadatan gerejawi di kalangan masyarakat Kristiani, kegiatan menyanyi baik dalam format 'paduan suara', nyanyian jemaat dan yang lain terintegrasi di dalam rangkaian ibadah peribadatan di gereja. Hal ini juga terdapat di kalangan anggota jemaat Gereja Batak Karo Protestan (GBKP) Runggun Benameriah yang juga menggunakan format paduan suara dalam kegiatan memuji dan memuliakan Tuhan. Bagi orang kristiani bernyanyi adalah kebutuhan rohani. Pada kedua gereja ini memiliki beberapa jenis paduan suara, baik paduan suara moria (kaum ibu), paduan suara mamre (kaum bapak) paduan suara permata atau pemuda/pemuda maupun paduan suara lansia. Setiap paduan suara memiliki seorang pelatih (amatir) yang juga bertindak sebagai pemimpin paduan suara, disebut sebagai Dirigen. Permasalahannya adalah bahwa sering sekali kualitas paduan suara yang ditampilkan rendah. Artinya selalu banyak kesalahan teknis dan suara yang tidak merdu dari anggota paduan suara pada saat penyajian paduan suara berlangsung. Bila kondisi ini berjalan dan terjadi terus menerus maka kehadiran paduan suara akhirnya dapat mengganggu terhadap pelaksanaan ibadah-ibadah. Kondisi yang lain bahwa hampir semua Dirigen yang ada di paduan suara GBKP adalah orang-orang yang memiliki kemampuan musikal yang terbatas, dan tidak mempunyai latar belakangi oleh pendidikan musik formal. Kemampuan manajerial serta kemampuan teknisnya untuk mengajar paduan suara sangat lemah. Rendahnya pengetahuan musical Dirigen serta kemampuan teknis, tentu saja akan memberikan dampak yang besar sekali terhadap kualitas suatu paduan suara yang dipimpinnya. Oleh karena itu tim pengabdian ini akan meningkatkan kemampuan manejemen paduan suara dalam materi vokal dan kemampuan conducting kepada semua peserta sehingga mampu meminimalisir kesulitan teknis yang ditemukan dalam persiapan dan penyajian paduan suara. Kegiatan pengabdian masyarakat ini diharapkan anggota dan dirigen/pemimpin paduan suara dapat memanfaatkan pengetahuan dan pengalaman mereka menjadi tenaga professional dalam bidang pelatihan paduan suara di kalangan anggota masyarakat secara umum.
\end{abstract}

Kata Kunci : Pelatihan, anggota dan dirigen paduan suara. 


\section{PENDAhuluan}

Ibadah adalah suatu suasana dimana sedang berlangsung pertemuan Allah dengan umatNya dalam pimpinan serta kehadiran Allah Tri-Tunggal. Pertemuan itu bersifat dialogis yang diwujudkan melalui liturgy. Ibadah adalah cara orang percaya mengalami, menghidupi, dan

merayakan karya keselamatan,penebusan, penyertaan, penguatan, penghiburan, dan penyembuan dari Allah. Dan disinilah fungsi liturgi menjadi sarana dan arena bagi jemaat dalam mengekspresikan ungkapan syukurnya kepada Allah.

Menyanyi dalam ibadah kristiani adalah kegiatan yang tidak dapat dipisahkan. Ada isitilah: 'dimana ada orang Kristen, disana pasti ada bernyanyi'. Demikian juga dalam realitanya, unsur bernyanyi dalam ibadah Kristen merupakan bahagian yang dominan. Bernyanyi yang dimaksud disini adalah: bernyanyi secara massal (jemaah), bernyanyi secara kelompok dalam jumlah besar (disebut paduan suara/koor), bernyanayi secara kelompok (kecil) disebut vocal group, trio, duet dan bernyanyi secara tunggal (solo). Semua ini membutuhkan skill (keterampilan secara musikal).

Situasi atau realitas yang ada di Gereja Batak Karo Protestan (GBKP) sehubungan dengan kegiatan nyanyian jemaat khususnya paduan suara Moria GBKP sangatlah menurun bahkan hampir tidak terdengar lagi nyanyian kelompok paduan suara dalam ibadah-ibadah gereja bahkan dalam perayaan hari besar gereja sekalipun, seperti perayaan hari Natal, Paskah, dll; dan kalaupun ada yang tampil, hasil atau kualitas paduan suara tersebut sangat tidak memadai. Tidak memadai maksudnya bahwa paduan suara itu tidak dipersiapkan dengan baik, sehingga hasil yang disajikan selalu tidak maksimal. Artinya banyak kesalahan teknis yang terjadi disaat penyajian paduan suara dimaksud. Untuk itu perlu diadakan pembekalan kepada anggota jemaat dan dirgen pada kelompok paduan suara pengetahuan tentang Paduan Suara dalam Ibadah.

\section{METODE PELAKSANAAN}

Metode pendekatan yang dilakukan dalam pelaksanaan pengabdian kelompok paduan suara Moria sebagai mitra adalah dengan cara melakukan pembekalan, pelatihan vokal dan teori musik secara perorangan dan secara kelompok ke team paduan suara, pembekalan dan pelatihan counducting (aba-aba) kepada dirigen/pimpinan paduan suara. Peningkatan pengetahuan dan keterampilan anggota dan dirigen/pemimpin paduan suara tentang konsep dan teori music, harmonisasi suara, olah vocal, teknik dasar conducting (pengaba) dan manajemen paduan suara, dilakukan dengan metode belajar dan praktek langsung ke pada anggota dan dirigen/pimpinan paduan suara.

Di harapkan melalui pengabdian ini anggota dan dirigen / pemimpin paduan suara dapat memanfaatkan pengetahuan dan pengalaman mereka menjadi tenaga professional dalam bidang pelatihan paduan suara di kalangan jemaat gereja anggota masyarakat secara umum.

\section{HASIL DAN PEMBAHASAN}

\subsection{Pengertian Musik}

Pengertian musik adalah sebagai berikut:

- Musik adalah cabang seni yang membahas dan menetapkan berbagai suara kedalam polapola-pola yang dapat dimengerti dan dipahami manusia

- Musik adalah ungkapan perasaan manusia bathin dan pemikiran manusia yang digunakan lewat media suara

- Musik yang adalah salah satu cabang seni

- Musik adalah salah satu bahagian dari budaya 


\subsection{Mengapa Jemaat Bernyanyi}

- Musik (nyanyian, paduan suara, instrument ) adalah sebagai salah satu unsur dari liturgi ( ibadah) dan bukan sekedar selingan ibadah ,tetapi mendapat posisi dan peranan yang paling mulia. Musik /nyanyian berfungsi untuk mendukung unsur-unsur ibadah/ liturgi, misalnya nyanyian pengakuan iman, dst.

- Sebagai pujian sesuai dengan tema nyanyian misalnya: ucapan syukur, pengakuan dosa, pengakuan iman, sebagai kesaksian, sebagai permohonan, dll.

- Musik (nyanyian/ instrument) sangat penting dalam ibadah, sebab sebagian besar porsi ibadah memiliki unsur musik, baik vokal maupun instrumental

\subsection{Fungsi Musik Secara Umum}

- Sebagai Ekspresi Emosional

- Sebagai Pengeintegrasian Masyarakat

- Sebagai Kesinambungan Masyarakat

- Sebagai Hiburan

- Sebagai Pengesahan Lembaga dan Norma-Norma Sosial Dalam Masyarakat

- Sebagai Komunikasi

- Sebagai Representatif Simbolik

- Sebagai Pendidikan

- Sebagai Kesinambungan Kebudayaan

- Sebagai Reaksi Jasmani

\subsection{Fungsi Musik Dalam Ibadah}

- Musik sebagai liturgi (unsur dari ibadah itu sendiri); pujian, pewartaan, perenungan, syukur, permohonan, persembahan, tekad, penyerahan diri / pernyataan iman, dsb

- Musik sebagai sarana bagi umat Kristen untuk menanggapi dan memberi respon terhadap apa yang disingkapkan Alkitab tentang Allah.

- Musik untuk mendidik dan menuntun jemaat

- Musik untuk menggembalakan jemaat

- Musik mempersatukan team penyanyi, jemaat juga jemaat dan penyanyi; baik pada permulaan , menyambut firman, komitment, dll.

- Musik sebagai pengantar susana ibadah (latar belakang pendukung terciptanya suasana hikmat); waktu pembukaan, saat teduh-pengakuan dosa, perjamuan kudus, dll

- Musik sebagai alat/sarana untuk memperindah ibadah; sebagai pendukung untuk baiknya pelaksanaan nyanyian.

- Pelayan Musik sebagai orang bertanggung jawab di dalam penyelenggaraan musik gereja dalam ibadah dibantu oleh banyak unsur antara lain paduan suara dan para pemusik. Paduan suara di dalam ibadah memiliki fungsi yang amat penting. Paduan suara tidak sekedar mengisi bagian "luang" di dalam ibadah atau sekedar selingan, menyanyi setelah khotbah. Paduan suara haruslah menjadi satu kesatuan dengan jemaat untuk menyampaikan nyanyian pujian dan ratapan kita kepada Tuhan.

- Fungsi paduan suara dalam ibadah sbb:

- Ibadah yang ada saat ini dapat menjadi lebih hidup jika jemaat disegarkan kembali dengan esensi ibadah tersebut, yaitu pengucapan syukur dan bakti kita pada Allah Bapa di sorga. Perayaan yang dirayakan,haruslah dengan penuh suka cita dan bukan sekedar formalitas menyanyikan nyanyian jemaat dan membaca beberapa bagian Alkita serta mendengar Pemberitaan Firman. Ibadah adalah perayaan. Semua dapat berperan serta aktif.

- Badah harus dipersiapkan. Semua telah memiliki tugas masing-masing dan semuanya harus saling bekerja sama. Jemaat adalah pemeran utama dalam ibadah, bukan para 
pelayan atau pemusik. Melalui nyanyian jemaat, jemaat dapat mengekspresikan ungkapan syukur mereka. Di samping itu, melalui nyanyian liturgis, mereka juga dapat menyampaikan doa-doa mereka serta respons mereka atas Firman Allah. Tanpa seorang pemimpin yang dapat menuntun jemaat supaya menyadari betapa pentingnya mereka di dalam ibadah, jemaat tidak akan tahu, apa yang sebenarnya terjadi di dalam ibadah itu.

- Itu sebabnya pembinaan sangat diperlukan. Ada berbagai macam cara untuk membina jemaat, antara lain melalui musik gereja. Bukan hanya orang dewasa tetapi juga anak-anak, para remaja serta pemuda-pemudi, mereka dapat belajar banyak melalui musik gereja.

- Seorang Pelayan Musik tidak sekedar bertugas untuk melatih paduan suara atau memainkan organ/piano. Pelayan Musik juga bertanggung jawab atas pembinaan warga jemaat bersama dengan Pelayan Firman. Fungsi tersebut bukan sekedar pelengkap tetapi benar-benar diperlukan di dalam jemaat.

\subsection{Penempatan Nyanyian Dalam Struktur Ibadah}

- Pujian - penyembahan (Praise / adoration). Nyanyian ini didasarkan atas kesadaran akan karya, kemahabesaran Allah.

- Pengakuan (Self awarenes / confession). Nyanyian ini merupakan pengakuan diri setelah bercermin pada kemahabesaran, karya / cinta Allah.

- Nyanyian berisikan pengampunan dan pendamaian (Absolition / reconciliation). Dibeberapa tradisi gereja (seperti katolik dan anglikan), nyanyian ini dinyanyikan oleh Pastor.

- Nyanyian syukur atas pengampunan / penebusan dosa

- Nyanyian Respons; baik terhadap firman, nyanyian persembahan.

- Nyanyian permohonan (Kyrie). Nyanyian ini dikombinasi dengan doa-doa.

- Nyanyian tekat / penyerahan diri (commitment / dedication). Nyanyian ini berakar pada semangat pembaharuan setelah menerima pengampunan dan Firman yang menuntun manusia dalam menjalankan kehidupan.

- Aklamasi (amen, haleluya, gloria, dll)

\subsection{Beberapa Efek Musik Gerejani}

Pemilihan atau penempatan musik harus lah sejalan /sesuai dan menyatu dengan srtuktur liturgi, dan itu akan menjadi sangat berfungsi :

- Musik rhytmical akan memberi semangat dan kesegaran fisik. Bila jenis musik ini dimainkan dalam tempo 90-an dan nuansa riang, maka efeknya akan memacu naiknya tempo jantung dan meningkatnya anti body yang diproduksi lewat tulang punggung, dan ini akan menimbulkan rasa kesegaran. Contoh; bila kita pernah mengikuti ibadah yang kontemporer, ada perasaan segar setelah pulang beribadah.

- Musik melodic sangat membantu manusia dalam mengekpressikan perasaannya, baik kekaguman, cinta, ketertekanan, permohonan, dsb. Secara psikologi, orang yang dapat dengan wajar mengekpressikan perasaannya akan merasa lega.

Sikap Bermusik (bernyanyi /bermusik Dalam Ibadah ):

- Bernyanyi bukan untuk penampilan / show, oleh karena itu harus dijaga jangan sampai menggeser kemuliaan Tuhan menjadi kemulian untuk manusia dalam penampilan musik dalam ibadah.

- Bernyanyi merupakan ungkapan perasaan dengan segenap hati kepada Tuhan, dengan demikian bernyanyi /bermusik adalah sarana ibadah bukan sebagai kebiasaan atau selingan dalam kebaktian. 
- Bernyanyi bukan untuk manusia tetapi untuk Tuhan, dengan demikian kita harus selalu waspada agar jangan sampai musik menjadi sesuatu yang dipakai untuk mempertunjukan keahlian bakat musik kita.

Lihat: Mzr 9: 2; 16: 8; Kol 3: 17, 23, 24.

\section{KESIMPULAN}

Adapun kesimpulan yang diperoleh dari kegiatan ini yaitu:

1. Musik sebagai liturgi (unsur dari ibadah itu sendiri); pujian, pewartaan, perenungan, syukur, permohonan, persembahan, tekad, penyerahan diri / pernyataan iman, dsb

2. Musik sebagai sarana bagi umat Kristen untuk menanggapi dan memberi respon terhadap apa yang disingkapkan Alkitab tentang Allah.

3. Musik untuk mendidik dan menuntun jemaat

4. Musik untuk menggembalakan jemaat

5. Musik mempersatukan team penyanyi, jemaat juga jemaat dan penyanyi; baik pada permulaan , menyambut firman, komitment, dll.

6. Musik sebagai pengantar susana ibadah (latar belakang pendukung terciptanya suasana hikmat); waktu pembukaan, saat teduh-pengakuan dosa, perjamuan kudus, dll

7. Musik sebagai alat/sarana untuk memperindah ibadah; sebagai pendukung untuk baiknya pelaksanaan nyanyian.

8. Pelayan Musik sebagai orang bertanggung jawab di dalam penyelenggaraan musik gereja dalam ibadah dibantu oleh banyak unsur antara lain paduan suara dan para pemusik. Paduan suara di dalam ibadah memiliki fungsi yang amat penting. Paduan suara tidak sekedar mengisi bagian "luang" di dalam ibadah atau sekedar selingan , menyanyi setelah khotbah. Paduan suara haruslah menjadi satu kesatuan dengan jemaat untuk menyampaikan nyanyian pujian dan ratapan kita kepada Tuhan.

\section{UCAPAN TERIMAKASIH}

Artikel ini merupakan salah satu hasil dari Program Pengabdian kepada Masyarakat yang Dibiayai oleh dana NON PNBP Universitas Sumatera Utara Sesuai dengan Surat Perjanjian Penugasan Pelaksanaan Pengabdian kepada Masyarakat Program Mono Tahun Dosen Muda Tahun Anggaran 2019. Oleh karena itu, diucapkan terima kasih kepada Rektor Universitas Sumatera Utara atas dukungan dana dan fasilitas yang diberikan. Terima kasih juga kepada Mitra pada kegiatan pengabdian ini.

\section{DAFTAR PUSTAKA}

Atmojo, Subronto K. 1985. Memimpin Paduan Suara. Jakarta: BPK Gunung Mulia Ester Gunawan Nasrani. 2003. "Rehearshal Technique". Paper disajikan pada Symposium on Church Choral Music, Bandung.

Kandisaputra, Tomyanto. (2003). "Basic Conducting Technique". Paper disampaikan pada Symposium on Church Choral Music, Bandung.

Listya, Agastya Rama. 2007. A-Z Direksi Paduan Suara. Jakarta: Yayasan Musik Gereja di Indonesia. 
ISSN Printed Version: 2549-4341

Frida Deliana et.al Training of Moria

Nicholson M. Sydney. 1985. Metode-metode Praktis untuk Paduan Suara. Jakarta: BPK Gunung Mulia.

Parto, FX Suharjo. 1996. Musik Seni Barat dan Sumber Daya Manusia. Yogyakarta: Pustaka Pelajar.

Sitompul, Binsar. 1986. Paduan Suara dan Pemimpinnya. Jakarta: BPK. Gunung Mulia.

Yamuger. 2000. Menjadi Diregen II - Membentuk Suara. Yogyakarta: Pusat Musik Liturgi.

Yamuger. 1993. Menjadi Dirigen III - Membina Paduan Suara. Yogyakarta: Pusat Musik Liturgi. 